\title{
An Investigation of the Selective Adsorptions of Metals on Mesoporous $\mathrm{NH}_{2}-\mathrm{MCM}-41$
}

\author{
Xinqing CHEN ${ }^{1,3}$, Wai Kwong CHING ${ }^{1}$, Koon Fung LAM ${ }^{1}$, Wei WEI ${ }^{3 *}$, \\ King Lun YEUNG ${ }^{1,2 *}$
}

${ }^{1}$ Department of Chemical and Biomolecular Engineering and ${ }^{2}$ Division of Environment, the Hong Kong University of Science and Technology, Clear Water Bay, Kowloon, Hong Kong, P.R. China

${ }^{3}$ CAS Key Laboratory of Low-carbon Conversion Science and Engineering, Shanghai Advanced Research Institute, Chinese Academy of Science, Shanghai 201210, P.R. China

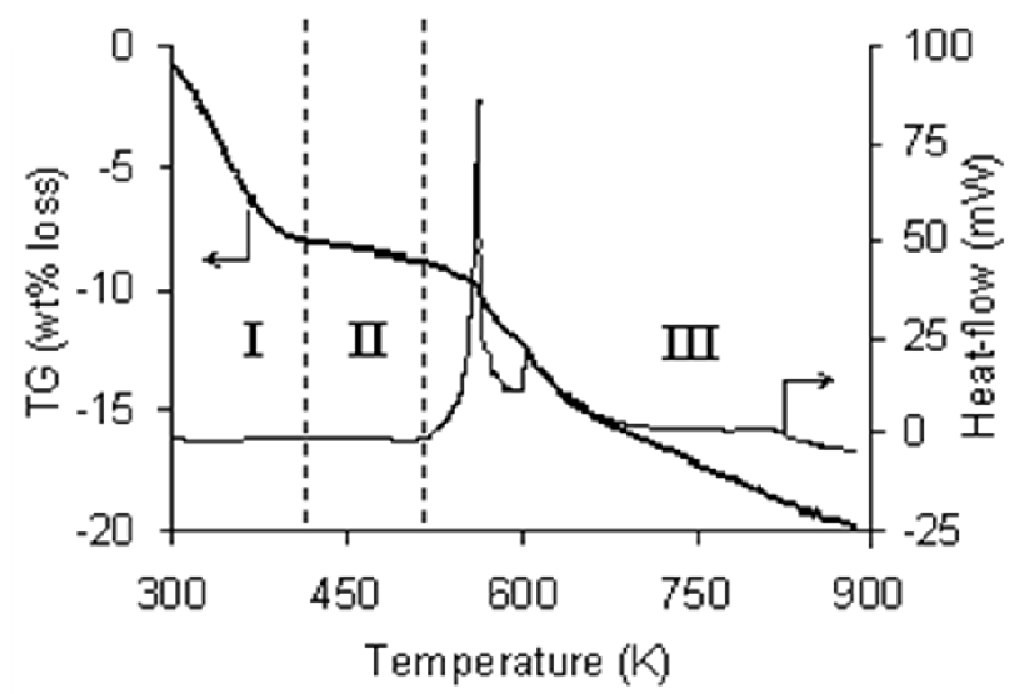

Figure S1. TGA/DTA analyses of $\mathrm{NH}_{2}-\mathrm{MCM}-41$

Author to whom correspondence should be addressed

King Lun YEUNG, Tel: +852 2358 7123; Fax: +852 2358 0054; e-mail: kekyeung@ust.hk 


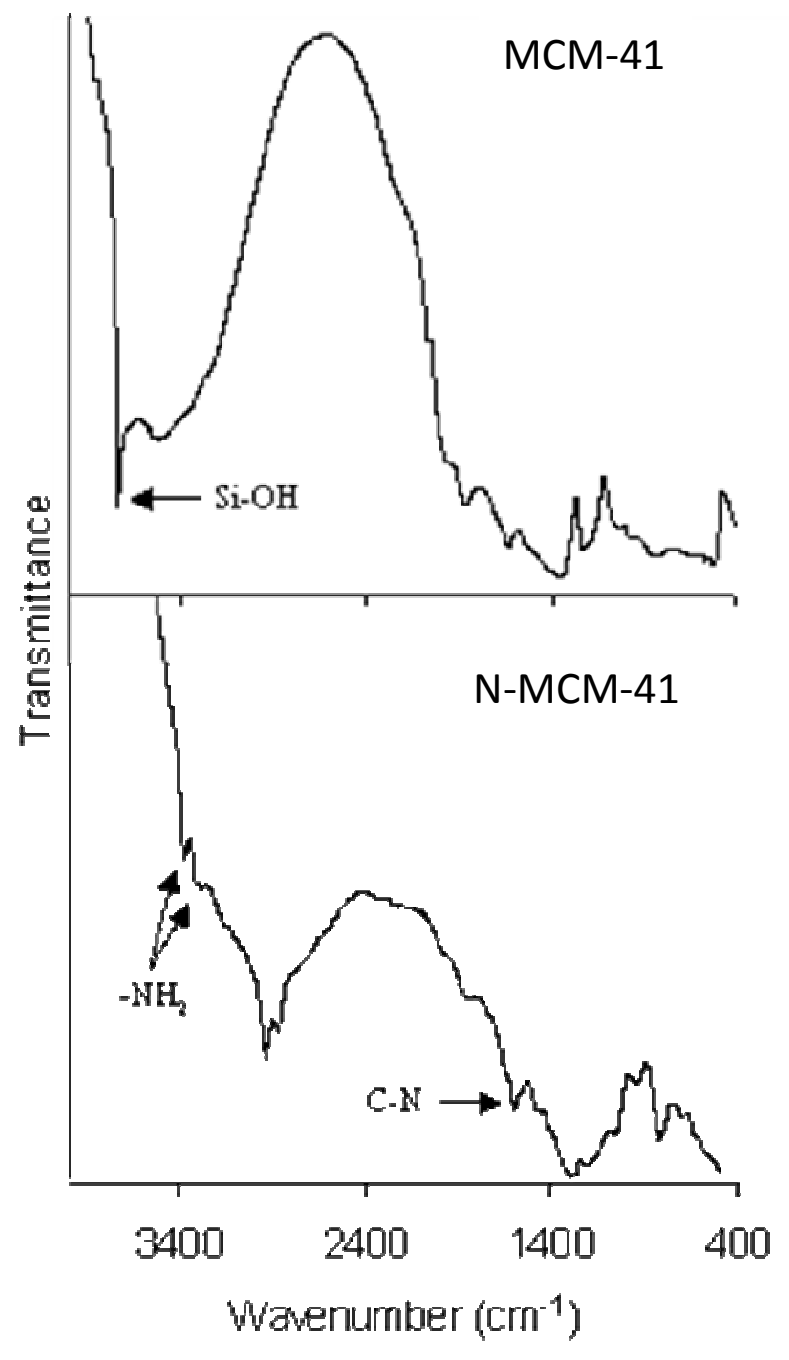

Figure S2. FT-IR analyses of MCM-41 and $\mathrm{NH}_{2}-\mathrm{MCM}-41$ 
Table S1. The single component adsorption capacity $(\mathrm{mmol} / \mathrm{g})$ of $\mathrm{Co}^{2+}, \mathrm{Ni}^{2+}, \mathrm{Cu}^{2+}$ and $\mathrm{Zn}^{2+}$ on MCM-41 and $\mathrm{NH}_{2}-\mathrm{MCM}-41$ respecitvely at room temperature.

\begin{tabular}{cllll}
\hline Adsorbents & $\mathrm{Co}^{2+}$ & $\mathrm{Ni}^{2+}$ & $\mathrm{Cu}^{2+}$ & $\mathrm{Zn}^{2+}$ \\
\hline MCM-41 & 0.01 & 0.01 & 0.01 & 0.01 \\
$\mathrm{NH}_{2}-\mathrm{MCM}-41$ & 0.64 & 0.70 & 0.76 & 0.73 \\
\hline
\end{tabular}


Table S2. Summary of the $\Delta \mathrm{H}$ and $\Delta \mathrm{S}$ values reported in the literature.

\begin{tabular}{cccccc}
\hline Metals & Adsorbents & Temperature $\left({ }^{\circ} \mathrm{C}\right)$ & $\Delta \mathrm{H}(\mathrm{kJ} / \mathrm{mol})$ & $\Delta \mathrm{S}(\mathrm{kJ} / \mathrm{mol} . \mathrm{K})$ & References \\
\hline $\mathrm{Co}^{2+}$ & Sepiolite & 20 & 4.12 & 0.068 & 1 \\
$\mathrm{Ni}^{2+}$ & $\mathrm{CNS}$ & 25 & 7.33 & 0.014 & 2 \\
& chitosan & 25 & 7.94 & 0.0304 & 3 \\
$\mathrm{Cu}^{2+}$ & MWCWTs & 22 & 61.38 & 0.281 & 4 \\
& chitosan & 25 & 11.16 & 0.0374 & 3 \\
$\mathrm{Zn}^{2+}$ & SBA-15 & 20 & 47.69 & 0.160 & 5 \\
\hline
\end{tabular}

1: Kara, M.; Yuzer, H.; Sabah, E.; Celik, M.S.; Adsorption of cobalt from aqueous solutions onto sepiolite. Water. Res. 2003, 37, 224-232.

2: Kumar, P.S.; Ramalingam, S.; Kirupha. S.D.; Murugesan, A.; Vidhyadevi, T.; Sivanesan, S.; Adsorption behavior of nick(II) onto cashew nut shell: Equilibrium, thermodynamics, kinetics, mechanism and process design. Chem. Eng. J. 2011, 167, 122-131.

3:Futalan, C.M.; Kan, C.C.; Dalida, M.L.; Hsien, K.J.; Pascua, C.; Wan, M.W.; Comparative and competitive adsorption of copper, lead, and nickel using chitosan immobilized on bentonite. Carbohydr. Polym. 2011, 83, 528-536.

4: Sheng, G.; Li, J.; Shao, D.; Hu, J.; Chen, C.; Chen, Y.; Wang, X.; Adsorption of copper (II) on multiwalled carbon nanotubes in the absence and presence of humic or fulvic acids. J. Hazard. Mater. 2010, 178, 333-340.

5: Da'na, E.; Sayari, A.; Adsorption of copper on amine-functionalized SBA-15 prepared by co-condensation: Equilibrium properties. Chem. Eng. J. 2011, 166, 445-453.

6: Lu, C.; Chiu, H.; Liu, C.; Removal of Zinc (II) from aqueous solution by purified carbon nanotubes: Kinetics and Equilibrium Studies. Ind. Eng. Chem. Res. 2006, 45, 2850-2855. 
The method for calculating multicomponent Freundlich model at different $\mathrm{pH}$ :

(1) The adsorption of $\mathrm{H}_{3} \mathrm{O}^{+}$on $\mathrm{NH}_{2}-\mathrm{MCM}-41$ was determined from the Zeta potential plot with two simplifying assumptions.

Assumption 1: The surface coverage of $\mathrm{H}_{3} \mathrm{O}^{+}$on $\mathrm{NH}_{2}-\mathrm{MCM}-41\left(\theta_{\mathrm{H} 3 \mathrm{O}}\right)$ is zero at the isoelectric point $\mathrm{pH}$.

Assumption 2: The surface coverage of $\mathrm{H}_{3} \mathrm{O}^{+}$on $\mathrm{NH}_{2}-\mathrm{MCM}-41\left(\theta_{\mathrm{H} 3 \mathrm{O}}\right)$ is $\sim 1$ at the highest positive surface Zeta potential.

Table S3 shows the calculations made from the Zeta-potential plot in Fig. 5a taken at room temperature. Figures $\mathrm{S} 3 \mathrm{a}$ and $\mathrm{S} 3 \mathrm{~b}$ plot $q_{\mathrm{H} 3 \mathrm{O}+}$ and $\theta_{\mathrm{H} 3 \mathrm{O}+}$ versus $\left[\mathrm{H}_{3} \mathrm{O}+\right]$ experimental data as well as model calculations from Freundlich adsorption model. It is clear that hydronium adsorption on the surface and protonation of the aminopropyls can be sufficiently described by a Freundlich equation.

Table S3. $\mathrm{H}_{3} \mathrm{O}^{+}$adsorption on $\mathrm{NH}_{2}-\mathrm{MCM}-41$ at $\mathrm{T}=25^{\circ} \mathrm{C}$

\begin{tabular}{|c|c|c|c|c|}
\hline $\mathrm{pH}$ & $\begin{array}{c}{\left[\mathrm{H}_{3} \mathrm{O}^{+}\right]} \\
(\mathrm{mmol} / \mathrm{L})\end{array}$ & $\begin{array}{c}\text { Zeta-potential } \\
(\mathrm{eV})\end{array}$ & $\Theta$ of $\left[\mathrm{H}_{3} \mathrm{O}^{+}\right]$ & $\begin{array}{l}\mathrm{q}_{\mathrm{H} 3 \mathrm{O}+} \\
(\mathrm{mmol} / \mathrm{g})\end{array}$ \\
\hline 5 & 0.01 & - & -- & -- \\
\hline 4.32 & 0.05 & - & -- & -- \\
\hline 3.96 & 0.11 & 0 & 0 & 0 \\
\hline 3.45 & 0.35 & 1.28 & 0.06 & 0.15 \\
\hline 3.06 & 0.87 & 2.575 & 0.13 & 0.28 \\
\hline 2.78 & 1.66 & 9.15 & 0.44 & 1.01 \\
\hline 2.51 & 3.09 & 15.25 & 0.74 & 1.70 \\
\hline 2.32 & 4.79 & 20.59 & 1.00 & 2.30 \\
\hline
\end{tabular}
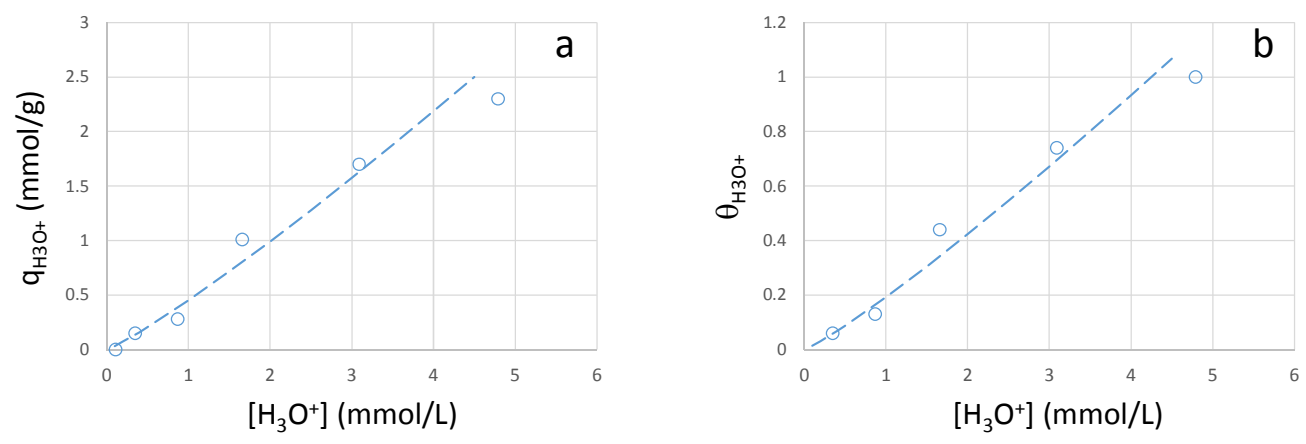
Figure S3 Plots of (a) adsorption isotherm $\left(q_{e}=0.45 C_{e}^{1.14}\right)$ and (b) surface coverage versus $\left[\mathrm{H}_{3} \mathrm{O}^{+}\right]\left(\theta_{e}=0.19 C_{e}^{1.14}\right)$ of hydronium ion on $\mathrm{NH}_{2}-\mathrm{MCM}-41$. Please note that symbols are experimental data and lines are model calculations.

(2) The single component adsorption of $\mathrm{Cu}^{2+}$ on $\mathrm{NH}_{2}-\mathrm{MCM}-41$ given Fig. $2 \mathrm{c}$ in the manuscript is replotted in Figure S4a and the corresponding surface coverage of $\mathrm{Cu}^{2+}, \theta_{\mathrm{Cu} 2+}$ is plotted in Figure S4b. Please note that the adsorption of $\mathrm{Cu}^{2+}$ on $\mathrm{NH}_{2}$-MCM-41 was carried out at $\mathrm{pH} 5$ where $\mathrm{H}_{3} \mathrm{O}^{+}$adsorption and surface protonation can be considered negligible (i.e., $\theta_{\mathrm{H} 3 \mathrm{O}+} \sim 0$ ).
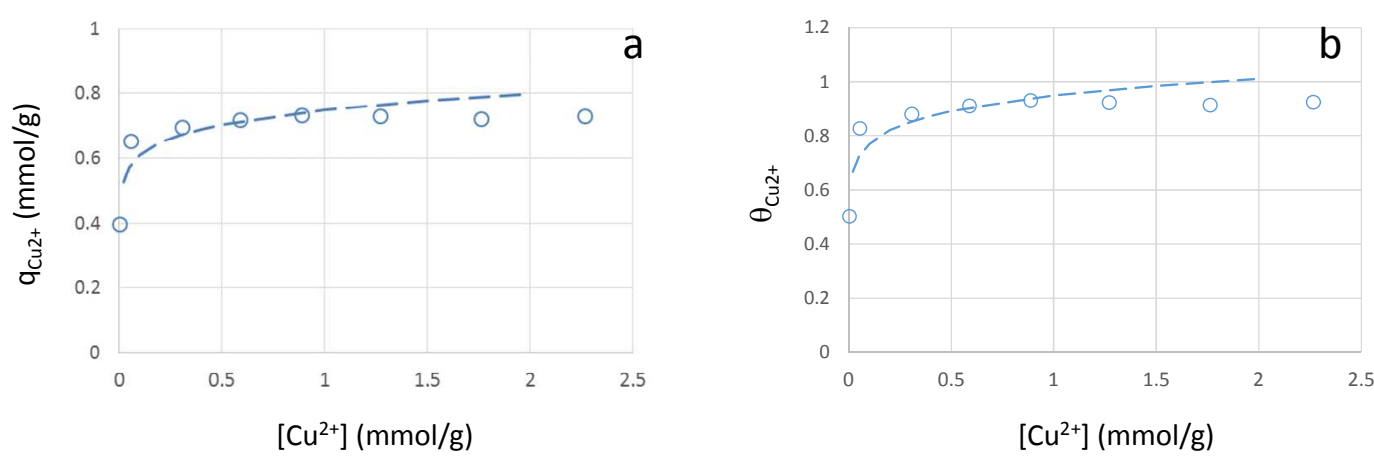

Figure S4 Plots of (a) adsorption isotherm $\left(q_{e}=0.75 C_{e}^{0.09}\right)$ and (b) surface coverage versus $\left[\mathrm{Cu}^{2+}\right]\left(\theta_{e}=0.95 \mathrm{C}_{e}^{0.09}\right)$ of copper ion on $\mathrm{NH}_{2}-\mathrm{MCM}-41$. Please note that symbols are experimental data and lines are model calculations.

(3) This gave us the Freundlich adsorption isotherms of $\mathrm{H}_{3} \mathrm{O}^{+}$and $\mathrm{Cu}^{2+}$ on $\mathrm{NH}_{2}$-MCM-41 at room temperature of $25^{\circ} \mathrm{C}$ as shown in the Equations $\mathrm{S} 1$ and $\mathrm{S} 2$, respectively. The adsorptions were expressed in term of $\theta_{\mathrm{H} 3 \mathrm{O}+}$ and $\theta_{\mathrm{Cu} 2+}$.

The Freundlich adsorption isotherms of $\mathrm{H}_{3} \mathrm{O}^{+}: \theta_{\mathrm{H3O+}}=0.19 C_{e}^{1.14} \quad$ Eqn.S1 The Freundlich adsorption isotherms of $\mathrm{Cu}^{2+}: \theta_{\mathrm{Cu} 2+}=0.95 \mathrm{C}_{e}^{0.09} \quad$ Eqn.S2

(4) Table S4 was prepared from the $\mathrm{Cu}^{2+}$ adsorption data of Fig. 5b. It tabulates the $p H,\left[\mathrm{H}_{3} \mathrm{O}^{+}\right]$and $\left[\mathrm{Cu}^{2+}\right]$, as well as the experimental $q_{\mathrm{Cu} 2+}$. The competition coefficient $\left(a_{i j}\right)$ between $\mathrm{H}_{3} \mathrm{O}^{+}$and $\mathrm{Cu}^{2+}$ was calculated according to Sheindorf et 
al. (1980) in reference [26] of the manuscript using the single-component Freundlich adsorption equations Eqns. S1 and S2. The calculated $a_{i j}$ of 2.6 was obtained by least square fitting. Please note this is obtained in term of $\theta$ (i.e., surface coverage).

Table S4. $\mathrm{Cu}^{2+}$ adsorption versus $\mathrm{pH}$ at $\mathrm{T}=25^{\circ} \mathrm{C}$

\begin{tabular}{cccc}
\hline $\mathrm{pH}$ & $\begin{array}{c}{\left[\mathrm{H}_{3} \mathrm{O}^{+}\right]} \\
(\mathrm{mmol} / \mathrm{L})\end{array}$ & $\begin{array}{c}{\left[\mathrm{Cu}^{2+}\right]} \\
(\mathrm{mmol} / \mathrm{L})\end{array}$ & $\begin{array}{c}\mathrm{qCu}^{2+} \text { in } \\
\text { experimental } \\
(\mathrm{mmol} / \mathrm{g})\end{array}$ \\
\hline 5 & 0.01 & 2.02 & 0.76 \\
4.32 & 0.05 & 2.10 & 0.73 \\
3.96 & 0.11 & 2.12 & 0.68 \\
3.45 & 0.36 & 2.29 & 0.51 \\
3.06 & 0.87 & 2.52 & 0.30 \\
2.78 & 1.66 & 2.62 & 0.25 \\
2.51 & 3.10 & 2.75 & 0.09 \\
2.32 & 4.79 & 2.86 & 0.01 \\
\hline
\end{tabular}

(5) The following model calculations were made for the $\mathrm{Cu}^{2+}$ adsorption from the $\mathrm{Cu}-\mathrm{Co}-\mathrm{Ni}$ ternary solutions at different pHs (cf. Fig. 9a in the manuscript).

The multicomponent Freundlich Equation (Eqn. S3) was used in the model calculations along with Eqns. S1 and S2 (i.e., single component Freundlich Equations for $\mathrm{H}_{3} \mathrm{O}^{+}$and $\mathrm{Cu}^{2+}$ adsorptions), and the competition coefficient, $a_{i j}$ of 2.6 for $\mathrm{H}_{3} \mathrm{O}^{+}$and $\mathrm{Cu}^{2+}$ using the experimental data from Fig. 5b. The same competition coefficients of $\mathrm{Cu}^{2+}-\mathrm{Co}^{2+}$ and $\mathrm{Cu}^{2+}-\mathrm{Ni}^{2+}$ from Table 5 are 0.006 and 0.001 , respectively. Please note $a_{i i}$ is 1.0 between $\mathrm{Cu}^{2+}-\mathrm{Cu}^{2+}$.

$$
q_{e, i}=K_{i} C_{e, i}\left(\sum_{j=1}^{N} a_{i j} C_{e, j}\right)^{n_{i}-1}
$$


The calculations are shown in Table $\mathrm{S} 5$ for $\mathrm{Cu}^{2+}$ adsorption from the $\mathrm{Cu}-\mathrm{Co}-\mathrm{Ni}$ ternary solution at different solution $\mathrm{pHs}$. Figure S5 plots the experimental data and model calculations. The plot shows that there is good agreement between model and experiment.

The process was used to calculate the relationship between metal ion adsorption and $\mathrm{pH}$ shown in the Figs. 7, 9 and $10 \mathrm{~b}$ in the manuscript.

Table S5. $\mathrm{Cu}^{2+}$ adsorption from Cu-Co-Ni ternary solution at different $\mathrm{pHs}$

\begin{tabular}{|c|c|c|c|c|c|c|c|}
\hline $\mathrm{pH}$ & $\begin{array}{c}{\left[\mathrm{H}_{3} \mathrm{O}^{+}\right]} \\
(\mathrm{mmol} / \mathrm{L})\end{array}$ & $\begin{array}{c}{\left[\mathrm{Cu}^{2+}\right]} \\
(\mathrm{mmol} / \mathrm{L})\end{array}$ & $\begin{array}{c}{\left[\mathrm{Co}^{2+}\right]} \\
(\mathrm{mmol} / \mathrm{L})\end{array}$ & $\begin{array}{c}{\left[\mathrm{Ni}^{2+}\right]} \\
(\mathrm{mmol} / \mathrm{L})\end{array}$ & $\begin{array}{c}\mathrm{q}_{\mathrm{Cu} 2+} \\
\text { experimental } \\
(\mathrm{mmol} / \mathrm{g})\end{array}$ & $\theta_{\mathrm{Cu} 2+}$ & $\begin{array}{c}\text { qcu2+ } \\
\text { Model Cal } \\
\text { (mmol/g) }\end{array}$ \\
\hline 5 & 0.01 & 2.02 & 2.07 & 2.06 & 0.78 & 0.99 & 0.79 \\
\hline 4.60 & 0.02 & 2.08 & 2.06 & 2.07 & 0.79 & 0.98 & 0.79 \\
\hline 4.32 & 0.05 & 2.10 & 2.08 & 2.11 & 0.79 & 0.95 & 0.76 \\
\hline 3.96 & 0.11 & 2.12 & 2.13 & 2.18 & 0.71 & 0.89 & 0.74 \\
\hline 3.45 & 0.36 & 2.29 & 2.17 & 2.32 & 0.65 & 0.72 & 0.70 \\
\hline 3.06 & 0.87 & 2.52 & 2.25 & 2.58 & 0.57 & 0.54 & 0.63 \\
\hline 2.78 & 1.66 & 2.62 & 2.6 & 2.7 & 0.42 & 0.39 & 0.42 \\
\hline 2.51 & 3.10 & 2.75 & 2.72 & 2.82 & 0.15 & 0.27 & 0.22 \\
\hline
\end{tabular}

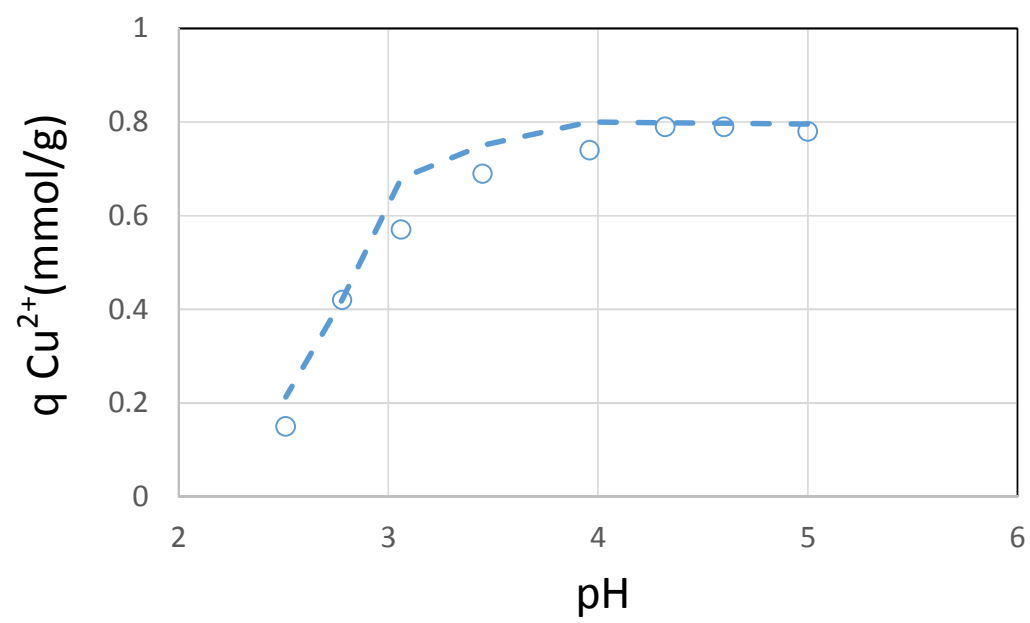

Figure 55 Plot of $\mathrm{Cu}^{2+}$ adsorption on $\mathrm{NH}_{2}-\mathrm{MCM}-41$ from Cu-Co-Ni ternary solutions at different pHs. Please note that symbols are experimental data and lines are model calculations. 
(6) It is important to note that this approach was possible as:

(a) the surface of $\mathrm{NH}_{2}-\mathrm{MCM}-41$ was relatively uniform,

(b) the range of $\mathrm{pHs}$ is narrow,

(c) there is only a single dominant ion specie within the $\mathrm{pH}$ range.

It would be more difficult to predict adsorption behavior on complex surfaces, as well as complex speciations and interactions at broader $\mathrm{pH}$ ranges. 